\title{
Genetic and non-genetic effects on calf vigor at birth and preweaning mortality in Nellore calves
}

\author{
Anita Schmidek ${ }^{1,2}$, Mateus José Rodrigues Paranhos da Costa ${ }^{2,3}$, Maria Eugênia Zerlotti \\ Mercadante ${ }^{4}$, Luciandra Macedo de Toledo ${ }^{2,5}$, Joslaine Noely dos Santos Gonçalves Cyrillo ${ }^{4}$, \\ Renata Helena Branco ${ }^{4}$
}

\author{
${ }^{1}$ APTA; Pólo Regional da Alta Mogiana, Colina, SP, Brazil. \\ ${ }^{2}$ Grupo ETCO - Grupo de Estudos e Pesquisas em Etologia e Ecologia Animal. \\ ${ }^{3}$ Departamento de Zootecnia, FCAV-UNESP, Jaboticabal, SP, Brazil. \\ ${ }^{4}$ Centro APTA Bovinos de Corte - IZ/APTA/SAA-SP, Sertãozinho, SP, Brazil. \\ ${ }^{5}$ Instituto de Zootecnia, Nova Odessa, SP, Brazil.
}

\begin{abstract}
The objective of the present study was to evaluate the genetic and non-genetic effects that influence vigor at birth and preweaning mortality in Nellore calves. A total of 11,727 records of births that occurred between 1978 and 2006, offspring of 363 sires, were analyzed. Poor calf vigor at birth (VB) and preweaning mortality divided into stillbirth (SB), early mortality (EM) and total mortality (TM) were analyzed as binary variables. Generalized linear models were used for the evaluation of non-genetic effects and generalized linear mixed models for genetic effects (sire and animal models). The incidences were $4.75 \%$ for $\mathrm{VB}, 2.66 \%$ for SB, $5.28 \%$ for EM, and $7.99 \%$ for TM. Birth weight was the effect that most influenced the traits studied. Calves weighing less than $22 \mathrm{~kg}$ (females) and less than $24 \mathrm{~kg}$ (males) were at a higher risk of low vigor and preweaning mortality. Preweaning mortality was higher among calves born from cows aged $\leq 3$ and $\geq 11$ years at calving compared with cows aged 7 to 10 years. Male calves presented less vigor and higher preweaning mortality than female calves. Selection for postweaning weight did not influence preweaning mortality. The heritability estimates ranged between 0.01 and 0.09 for $\mathrm{VB}, 0.00$ and 0.27 for $\mathrm{SB}, 0.03$ and 0.17 for EM and 0.02 and 0.10 for TM. Stillbirth should be included as a selection criterion in breeding programs of Nellore cattle, alone or as part of a selection index, aiming to reduce preweaning mortality.
\end{abstract}

Key Words: animal welfare, beef cattle, calf mortality, genetic improvement, risk factor

\section{Introduction}

Preweaning mortality is an important economic component of farming systems since it reduces the number of animals available for sale (Østerås et al., 2007), compromises animal well-being (Hansen et al., 2003), and reduces the number of animals available for selection as well as genetic progress (Fuerst-Waltl \& Fuerst, 2010; Meyer et al., 2001).

Reviews on the effects that influence preweaning mortality of calves were published by Mee (2008) and Meijering (1984). The most recurrent fixed effects are dystocia, age of dam at calving, and sex and birth weight of the calf (Azzam et al., 1993; Johanson \& Berger, 2003; Meijering, 1984). The heritability estimates for mortality are usually of low to medium magnitude, ranging from 0.00 to 0.26 depending on breed, cow age, mortality period, and model of analysis used (Fuerst-Waltl \& Fuerst, 2010; Koots et al., 1994; Martinez et al., 1983).
Most studies on calf mortality have investigated stillbirth in dairy breeds. Investigations evaluating preweaning death in beef cattle are less frequent. One reason for this fact is the lower availability of records as reported by Bleul (2011), since in many countries preweaning mortality is only recorded in dairy herds. The number of studies is even lower for Bos indicus animals (Riley et al., 2004). The authors of the present study found no article investigating the genetic and non-genetic effects that influence preweaning mortality in Nellore calves. The Nellore breed accounts for a large part of the Brazilian cattle herd (Albuquerque et al., 2006) and the country is currently one of the leading exporters of beef meat of the world.

The objective of the present study was to evaluate the genetic and non-genetic effects that affect vigor at birth (VB) and preweaning mortality of Nellore calves in order to expand knowledge of the incidence and additive genetic variability of these traits as a way to reduce mortality before weaning. 


\section{Material and Methods}

Records of VB and preweaning mortality of purebred Nellore calves were obtained from Centro APTA Bovinos de Corte, a research center of Instituto de Zootecnia (IZ), and from Fazenda Mundo Novo (MH). Both farms are located in the southeastern region of Brazil, which is characterized by a humid tropical climate with mean temperatures of 21 to $24{ }^{\circ} \mathrm{C}$ and annual rainfall of 1312 to $1584 \mathrm{~mm}$. The pastures consist mainly of Panicum maximum, Brachiaria brizantha and Brachiaria decumbens.

In 1980 the Nellore herd at IZ was subdivided into two herds: a "selection" herd, selected for higher postweaning weight and a "control" herd, selected for the average for postweaning weight. The two herds were kept in the same environment. Further details about the herd and the selection process were described by Mercadante et al. (2003).

The following records were excluded: i) no information about paternity, age of dam at calving, sex or date of birth of the calf, and ii) calves originating from embryo transfer, abortions or twin pregnancies. After editing the data, 11,727 birth records were used, including 7,384 births that occurred at IZ between 1978 and 2006, and 4,343 births that occurred at MH between 2002 and 2006. The calves were born from 3,602 dams and 363 sires. The herds were connected by 15 sires used in both herds.

The calves were identified and weighed within the first 24 hours after birth, period when data regarding stillbirth and vigor were also recorded. The calves were weaned at an average age of 7 months.

Vigor at birth (VB) was defined as 1 (low vigor: calves classified as stillborn, weak, abandoned, rejected by the mother, calves that could not nurse on their own, and calves with some physical defect), or as 0 (adequate vigor: all other calves).

Preweaning mortality was evaluated at three periods (Table 1): stillbirth (SB), early mortality (EM) and total mortality (TM), defined as 1 (calves that died within a period) or as 0 (calves that did not die within that period). Thus, SB included stillborn and not viable (malformed)

Table 1 - Records numbers and incidence of vigor at birth (VB), stillbirth (SB), early mortality (EM) and total mortality (TM)

\begin{tabular}{lcccc}
\hline Trait & VB & SB & EM & TM \\
\hline Calf number & 11,727 & 11,727 & 11,652 & 11,727 \\
Poor-vigor calves & 557 & - & - & - \\
Calf death & - & 312 & 615 & 937 \\
Incidence (\%) & $4.75^{1}$ & 2.66 & 5.28 & 7.99 \\
\hline
\end{tabular}

${ }^{1}$ Incidence of low vigor calves whose death occurred at birth or up to 72 hours of life. EM comprised all deaths that occurred before the first month of life, and TM included all deaths that occurred until weaning.

In order to identify important effects on the traits studied the GENMOD procedure of software SAS (Statistical Analysis System, version 9.0) was used to fit generalized linear models to the data. In addition to the main effects, all two-way interactions were tested, which were not significant $(\mathrm{P}>0.05)$ except for the interaction between birth weight and sex. Therefore, birth weight classes were created for each sex.

The models included the fixed effects of farm (IZ; MH), year of birth of the calf (1978 to 2006), period of birth of the calf (August to October; November to January), sex (male; female), birth weight class defined according to the mean and standard deviation of the trait for each sex (females: $\leq 22 \mathrm{~kg} ; 23$ to $26 \mathrm{~kg} ; 27$ to $31 \mathrm{~kg} ; 32$ to $35 \mathrm{~kg}$; $\geq 36 \mathrm{~kg}$; males: $\leq 24 \mathrm{~kg} ; 25$ to $28 \mathrm{~kg} ; 29$ to $34 \mathrm{~kg} ; 35$ to 38 $\mathrm{kg} ; \geq 39 \mathrm{~kg}$ ), class of inbreeding ( $0 \% ;>0$ to $2 \%$; $>2$ to $4 \%$; $>4 \%$ ), and class of dam age at calving ( 2 and 3 years; 4 to 6 years; 7 to 10 years; $\geq 11$ years). The model for SB did not include the effect of birth weight since this information was only available in $53.5 \%$ of the records.

Odds ratios were calculated for VB and mortality. According to Johanson \& Berger (2003), the odds ratio compares two opposite probabilities to determine which one has the higher chance of occurrence. The significance of the odds ratio is given by the confidence interval, usually the $95 \%$ confidence interval. Reference classes were established to evaluate the risk of occurrence in one class compared with the reference class. In the present study, the reference class was defined as the class presenting the lowest chance of occurrence of the problem.

The effect of selection for postweaning weight on the four traits studied was evaluated using only the records of births that occurred between 2002 and 2006 at IZ by calculating the odds ratio of herd effect (selection: 454 animals; control: 244 animals). The animals of the two herds were kept together in the same environment and received the same treatments. Therefore, it is expected that phenotypic differences in vigor and mortality correspond to genetic differences between herds.

For genetic analysis, the deaths from accidents were excluded from the dataset. For the genetic analysis of VB, stillbirths were also excluded. A numerator relationship matrix containing 15,607 animals was computed, tracing back up to four generations from the calves studied. In all analysis, except for Model 3, the traits were considered as calf traits. 
A sire model (Model 1) was fitted to estimate the genetic parameters of the studied traits (Guerra et al., 2006). The mixed model can be described as:

$$
\mathrm{Y}=\mathrm{Xb}+\mathrm{Z}_{1} \mathrm{t}+\mathrm{Z}_{2} \mathrm{gc}+\mathrm{e}
$$

where $Y=$ vector of the binary responses of vigor and mortality at the three time points $(1=$ low vigor or $0=$ adequate vigor; $1=$ dead, $0=$ alive); $b=$ vector of fixed effects; $t=$ vector of random effects of the sire (father of calf); $g c=$ vector of random effects of the contemporary group; and $e=$ vector of random residual effects. $X, Z_{1}$ and $Z_{2}$ are incidence matrices that relate the vectors of fixed and random effects to the response vector. The models included the fixed effects of sex (male; female) and class of dam age at calving ( 2 and $3 ; 4$ to 6 ; and 7 to $10 ; \geq 11$ years old). The contemporary group was formed by farm (IZ; MH), year (1978 to 2006) and period of birth (August to October; November to January) and was included as a random effect to avoid problems resulting from the occurrence of subclasses without variability, i.e., absence of low vigor or death (Misztal et al., 1989).

In addition, same animal models, with the same fixed effects described above, were fitted. As regards random effects, these models were defined: Model 2: additive genetic effects $(a)$, maternal permanent environment effects $(c)$, contemporary group effects $(C G)$ and residual effects (e); Model 3: like Model 2, but considering the analyzed variables as dam traits; Model 4: additive genetic effects $(a)$, maternal genetic effects $(m)$, maternal permanent environment effects $(c)$, contemporary group effects $(C G)$ and residual effects $(e)$.

(Co)variance components were obtained by approximate restricted maximum likelihood estimation in univariate analysis using the ASREML program (Gilmour et al., 2008). A generalized linear mixed model with a logit link function was fitted, which implies the correction of residual variance by the factor $\pi^{2} / 3$ (Southey et al., 2003). The logistic model uses a link function $g(\pi)$, which links the expected value to the linear predictor $\eta_{i}$ (Maxa et al., 2009). Convergence was reached when the change in log likelihood was less than 0.002 between two consecutive iterations and the change in the parameter estimate of individual variance was less than $1 \%$ (Gilmour et al., 2008).

Total variance estimates for sire model were computed as the sum of sire variance, contemporary group variance and residual variance. Heritability (trait of the calf) was estimated as:

$$
\mathrm{h}^{2}=4 * \operatorname{Var}_{\text {sire }} / \operatorname{Var}_{\text {total }}
$$

where $V a r_{\text {sire }}$ corresponds to the genetic variance component of the sire and $\mathrm{Var}_{\text {total }}$ corresponds to total phenotypic variance.

\section{Results and Discussion}

In the present study, $74 \%$ of the calves with low vigor records died before weaning. The incidence of low vigor (Table 1) was about $50 \%$ lower than the rate reported by Riley et al. (2004) for Brahman calves (10.6\%). Although daily temperature data was not available in the present study, the occurrence of days with minimum temperatures lower than or equal to $5.6{ }^{\circ} \mathrm{C}$ was not common during the calving season. This could in part explain the lower rate of calves with poor vigor in the present study compared with the Brahman study.

The mortality rates observed (Table 1) were coherent with those reported in the literature, although most data refer to Bos taurus animals. Stillbirth rates ranged from $1.4 \%$ to $11 \%$ and deaths from birth to weaning ranged from $3.2 \%$ to $10.8 \%$ (Bleul, 2011; Eriksson et al., 2004; Meyer et al., 2001; Riley et al., 2004). The mortality rate declined with increasing age of the calf, with the observation of a larger number of deaths in the first days of life, particularly up to 30 days (Figure 1).

Concerning the causes of death (Table 2) identified, weakness was the most frequent, occurring mainly during the first 15 days of life. With respect to death due to diseases, diarrhea was the main cause $(28.6 \%)$, followed by inflammation of the navel (21.4\%). The main causes of death due to accidents were snakebites $(30.8 \%)$ and falling into ditches $(13.3 \%)$.

The year of birth and farm effects were significant for the four traits studied $(\mathrm{P}<0.05)$. Period of birth effect was only significant for TM $(\mathrm{P}<0.05)$, with $13 \%$ greater odds of death for calves born between November and January,

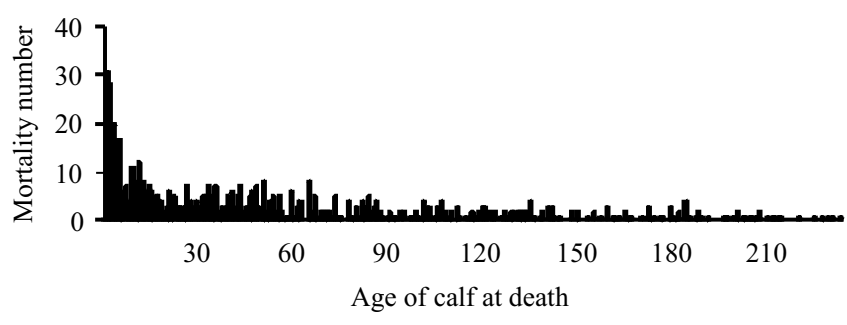

Figure 1 - Distribution of calf mortality number by the age of calf (days) at death.

Table 2 - Causes of pre-weaning death, with corresponding mean ages at death

\begin{tabular}{lrc}
\hline Cause of death & $\%$ & Age (days) \\
\hline Weakness (\%) & 49.36 & 16.68 \\
Disease (\%) & 12.75 & 71.79 \\
Accident (\%) & 4.46 & 62.80 \\
Unknown (\%) & 33.43 & 73.14 \\
\hline
\end{tabular}


comparing with those born between August and October. These results are probably related to high humidity and temperature in this period, ideal weather conditions for the development of screwworms, usually in the navel of the young born calves. This condition, if not detected in the first days of occurrence, can lead the calf to death.

The effect of inbreeding class was not significant for any of the traits $(\mathrm{P}>0.05)$. The remaining fixed effects included in the models are expressed in relation to the class of effect of lowest incidence (reference class) (Table 3). Birth weight was the main cause of low vigor and preweaning death. Calves born with intermediate weights presented better vigor and lower mortality than the other animals $(\mathrm{P}<0.01)$. In a preliminary analysis of SB using part of the sample studied for which the birth weight data was available and the effect of birth weight class was included in the model, the risk of death was 5.5 times higher for lighter calves $(\mathrm{P}<0.01)$ when compared with those with intermediate weights, and 2.9 times higher $(\mathrm{P}<0.01)$ for heavier calves.

There is consensus regarding the negative impact of extreme birth weights on calf mortality, which normally shows a quadratic trend (Bleul, 2011; Guerra et al., 2006; Johanson \& Berger, 2003; Martinez et al., 1983). There is also a consensus that lighter calves are at a higher risk of death than heavier animals, even considering the occurrence of dystocia in heavier calves (Katoch et al., 1994; Koch et al., 1994; Rawal \& Tomar, 1994).

The risk of low vigor and death was about $20 \%$ higher among male calves compared with female animals $(\mathrm{P}<0.01)$ (Table 3). This difference is frequently reported in the literature, with the incidence of preweaning mortality sometimes being twice as high in males compared to females (Azzam et al., 1993; Bleul, 2011; Riley et al., 2004). One common explanation for the association between sex and birth weight is the higher weight of males that results in calving difficulties which, in turn, increase the risk of death. This is in contrast to the present study in which calving difficulties were rare $(0.3 \%)$. An alternative explanation was provided by Machado Neto et al. (1997), who found higher concentrations of immunoglobulins in female calves, a fact that may increase the chance of survival of that gender.

Age of dam at calving was the second most important effect influencing preweaning mortality, with the probability of calf loss tending to be lower for adult cows. The risk of death was about $20 \%$ higher among calves born to cows aged 2 and 3 years and older than 11 years than among those born to cows aged 7 to 10 years (Table 3 ). Calf vigor was not influenced by age of dam at calving $(\mathrm{P}>0.05)$.

There is consensus in the literature that age of dam at calving affects preweaning mortality. This influence is usually lower during adult life, whereas higher offspring mortality is observed at the beginning of the reproductive life of the cow and, to a lesser extent, at the end of this period (Azzam et al., 1993; Bleul, 2011; Riley et al., 2004).

Despite the identification of the risk factors for calf death, their mechanisms of action remain unclear. In this respect, further studies are needed to elucidate these mechanisms and to develop more efficient care strategies for high-risk animals.

No significant difference in the four traits studied was detected between the selection and control herds $(\mathrm{P}>0.05)$. A similar result was reported by Cundiff et al. (1998), who found no effect of selection for higher yearling weight.

Studying the same herds over 22 years of selection for postweaning weight, Mercadante \& Razook (2010) reported large difference for birth weight genetic trends between the two herds $(0.67 \%$ and $-0.03 \%$ of the annual mean for the selection and control herds, respectively). In addition to

Table 3 - Number of observations (N) for each category, odds ratios and corresponding standard errors of vigor at birth (VB) and stillbirth (SB), early mortality (EM) and total mortality (TM)

\begin{tabular}{|c|c|c|c|c|c|}
\hline Trait & $\mathrm{N}$ & VB & SB & EM & TM \\
\hline \multicolumn{6}{|l|}{ Birth weight (o; 우) } \\
\hline$\leq 24 ; \leq 22 \mathrm{~kg}$ & 579 & $3.89 \pm 0.34^{* *}$ & - & $2.82 \pm 0.23 * *$ & $2.25 \pm 0.16^{* *}$ \\
\hline $25-28 ; 23-26 \mathrm{~kg}$ & 2445 & $1.61 \pm 0.11^{* *}$ & - & $1.39 \pm 0.08 * *$ & $1.26 \pm 0.06^{* *}$ \\
\hline $35-38 ; 32-35 \mathrm{~kg}$ & 2573 & $1.27 \pm 0.09^{* *}$ & - & $1.03 \pm 0.07$ & $1.03 \pm 0.06$ \\
\hline$\geq 39 ; \geq 36 \mathrm{~kg}$ & 564 & $2.23 \pm 0.19^{* *}$ & - & $1.88 \pm 0.16^{* *}$ & $1.72 \pm 0.12 * *$ \\
\hline \multicolumn{6}{|l|}{ Sex } \\
\hline \multicolumn{6}{|l|}{ Age of dam } \\
\hline $2-3$ years & 2025 & $1.11 \pm 0.08$ & $1.29 \pm 0.10^{* *}$ & $1.28 \pm 0.08 * *$ & $1.33 \pm 0.07 * *$ \\
\hline $4-6$ years & 4062 & $0.96 \pm 0.06$ & $1.06 \pm 0.07$ & $1.05 \pm 0.06$ & $1.07 \pm 0.05$ \\
\hline $7-10$ years & 3776 & $\mathrm{RC}$ & $\mathrm{RC}$ & $\mathrm{RC}$ & $\mathrm{RC}$ \\
\hline$\geq 11$ years & 1864 & $1.12 \pm 0.08$ & $1.02 \pm 0.09$ & $1.15 \pm 0.08^{*}$ & $1.20 \pm 0.07 * *$ \\
\hline
\end{tabular}

* $\mathrm{P}<0.05 ; * * \mathrm{P}<0.01 ; \mathrm{RC}-$ reference class. 
correlated genetic changes in birth weight, a genetic change in cow weight was also observed in the experimental herds studied $(0.38 \%$ of the annual mean) (Mercadante et al., 2004). These cows had a mean weight of $431.9 \mathrm{~kg}$, resulting in a calf-to-cow weight ratio of $7.0 \%$, a value close to the optimal ratio of $7.2 \%$, due to the reduced mortality of $3.1 \%$ (Johanson \& Berger, 2003). These authors reported higher mortality for calf-to-cow weight ratio of $4.5 \%$ and 9.3\% (corresponding to 8.2 and $5.7 \%$ of calf mortality, respectively). Considering the larger birth weight of calves from the selection herd compared with the control herd, an increase in the dystocia rates could be expected, which in turn could increase preweaning mortality occurrence in selection herd. We can hypothesize that the near optimum calf-to-cow weight ratio in selection herd could partly be due an adjustment between cow and calf size, avoiding de increase in occurrence of dystocia and consequently, in mortality rates.

Although VB showed to be a valuable phenotypic indicator of calf death risk, selection against low vigor would not be efficient, since heritability $\left(\mathrm{h}^{2}\right)$ for this trait was low (Table 4). The results are in agreement with the estimates reported by Riley et al. (2004) for birth vigor of Brahman calves, but in the present study, even lower direct heritabilities than those were estimated.

Direct heritability estimates for mortality showed a tendency to decrease as the calves approached weaning age (Table 4). The result can be interpreted as a reflection of greater environmental influence on deaths that occur at older ages. A similar trend was reported by Alencar
(1982) for Canchim calves and by Cundiff et al. (1998), who studied various genetic groups. Goyache et al. (2003), evaluating the Asturiana de los Valles cattle breed, reported a trend towards higher $\mathrm{h}^{2}$ for mortality up to 72 hours of life when compared with deaths that occurred between 72 hours and weaning, but a higher $\mathrm{h}^{2}$ was observed when the whole period was considered.

The present results indicate the possibility of reducing SB through direct selection against the trait (Table 4). Although results will only be obtained in the medium or long term, their effects will be permanent in the herd. In a review, Koots et al. (1994) reported mean heritabilities of 0.06 and 0.12 for SB of cows and heifers, respectively. Cundiff et al. (1998) and Goyache et al. (2003) found similar $\mathrm{h}^{2}$ estimates of about 0.10 . On the other hand, very low heritabilities of 0.00 to 0.04 have been reported by Meyer et al. (2001), Eriksson et al. (2004) and Fuerst-Waltl $\&$ Fuerst (2010).

Results from animal models analysis (Table 4) indicated that SB is more influenced by calf than by dam traits, supporting the importance of the direct additive component for the expression of SB. Goyache et al. (2003) found 2-fold higher heritability estimates of perinatal survival when considered as a calf trait rather than as a dam trait.

Heritability for EM was lower than that estimated for $\mathrm{SB}$, with similar results when considering EM as a calf or as a dam trait (Table 4). In a study on mortality in the first month of life, Fuerst-Waltl \& Fuerst (2010) estimated an $\mathrm{h}^{2}$ of 0.006 with a linear sire model and of 0.08 with a threshold sire model considering mortality between 72

Table 4 - Variance components and genetic parameters for vigor at birth (VB), stillbirth (SB), early mortality (EM) and total mortality (TM)

\begin{tabular}{|c|c|c|c|c|c|c|c|c|c|}
\hline & Var(a) & $\operatorname{Var}(\mathrm{m})$ & $\operatorname{Var}(\mathrm{c})$ & $\mathrm{CG}$ & $\operatorname{Var}(\mathrm{e})^{\mathrm{i}}$ & $\operatorname{Var}(\mathrm{T})$ & $\mathrm{h}^{2} \pm \mathrm{SE}$ & $\mathrm{m}^{2} \pm \mathrm{SE}$ & $\mathrm{c}^{2} \pm \mathrm{SE}$ \\
\hline \multicolumn{10}{|l|}{ VB } \\
\hline Model 1 & 0.03 & - & - & 1.57 & 3.29 & 4.89 & $0.03 \pm 0.04$ & - & - \\
\hline Model 2 & 0.09 & 0.42 & - & 1.51 & 3.29 & 5.31 & $0.02 \pm 0.03$ & - & $0.08 \pm 0.03$ \\
\hline Model 3 & - & 0.44 & 0.08 & 1.36 & 3.29 & 5.17 & - & $0.09 \pm 0.05$ & $0.10 \pm 0.03$ \\
\hline Model 4 & 0.03 & 0.43 & 0.07 & 1.35 & 3.29 & 5.17 & $0.01 \pm 0.03$ & $0.08 \pm 0.05$ & $0.10 \pm 0.03$ \\
\hline \multicolumn{10}{|l|}{ SB } \\
\hline Model 1 & 0.27 & - & - & 0.37 & 3.29 & 3.93 & $0.27 \pm 0.11$ & - & - \\
\hline Model 2 & 0.61 & - & $0.00^{\mathrm{ii}}$ & 0.32 & 3.29 & 4.22 & $0.15 \pm 0.05$ & - & $0.00 \pm 0.00$ \\
\hline Model 3 & - & 0.35 & $0.00^{\mathrm{ii}}$ & 0.40 & 3.29 & 4.04 & - & $0.09 \pm 0.05$ & $0.09 \pm 0.05$ \\
\hline Model 4 & 0.19 & $0.00^{\mathrm{ii}}$ & $0.00^{\mathrm{ii}}$ & 0.30 & 3.29 & 3.78 & $0.14 \pm 0.05$ & $0.00 \pm 0.00$ & $0.00 \pm 0.00$ \\
\hline \multicolumn{10}{|l|}{ EM } \\
\hline Model 1 & 0.16 & - & - & 0.17 & 3.29 & 3.62 & $0.17 \pm 0.07$ & - & - \\
\hline Model 2 & 0.23 & - & 0.19 & 0.18 & 3.29 & 3.89 & $0.06 \pm 0.04$ & - & $0.05 \pm 0.02$ \\
\hline Model 3 & - & 0.20 & 0.13 & 0.20 & 3.29 & 3.82 & - & $0.05 \pm 0.04$ & $0.09 \pm 0.04$ \\
\hline Model 4 & 0.20 & 0.13 & 0.10 & 0.17 & 3.29 & 3.89 & $0.05 \pm 0.04$ & $0.03 \pm 0.04$ & $0.06 \pm 0.04$ \\
\hline \multicolumn{10}{|l|}{$\mathrm{TM}$} \\
\hline Model 1 & 0.09 & - & - & 0.10 & 3.29 & 3.48 & $0.10 \pm 0.05$ & - & - \\
\hline Model 2 & 0.17 & - & 0.21 & 0.10 & 3.29 & 3.77 & $0.05 \pm 0.03$ & - & $0.06 \pm 0.03$ \\
\hline Model 3 & - & 0.15 & 0.17 & 0.11 & 3.29 & 3.72 & - & $0.04 \pm 0.03$ & $0.09 \pm 0.03$ \\
\hline Model 4 & 0.15 & 0.05 & 0.18 & 0.09 & 3.29 & 3.76 & $0.04 \pm 0.03$ & $0.02 \pm 0.03$ & $0.06 \pm 0.03$ \\
\hline
\end{tabular}

$\mathrm{CG}$ - contemporary group; SE - standard error.

${ }^{\mathrm{i}}$ Residual variance restricted to $\pi^{2} / 3$.

ii Bounded. 
hours of life and weaning. Goyache et al. (2003) reported $\mathrm{h}^{2}$ estimates for late mortality as a calf trait ranging from 0.06 to 0.11 , with very low maternal genetic influence.

The low $\mathrm{h}^{2}$ estimate for TM (Table 4) indicates that this trait was more influenced by environmental factors than by genetic factors. Similar $\mathrm{h}^{2}$ estimates for TM have been reported by Cundiff et al. (1998) and Riley et al. (2004), with values ranging from 0.04 to 0.06 . Other investigators obtained higher $\mathrm{h}^{2}$, ranging from 0.11 to 0.20 (Alencar, 1982; Cundiff et al., 1986; Goyache et al., 2003; Guerra et al., 2006).

The results indicate the possibility of reducing SB through direct selection. Since SB accounted for more than one-third of TM, this selection should also reduce TM. In this respect, Fuerst-Waltl \& Fuerst (2010) estimated a genetic correlation of $0.90 \pm 0.06$ between calf mortality until the first month of life and from the first month to weaning.

\section{Conclusions}

The survival of Nellore calves depends on various factors that involve the simultaneous action of genetic and environmental effects. Birth weight is highly relevant for the definition of calf vigor and, therefore, for the chance of survival until weaning. In order to reduce the risk of calf loss, strategies for environmental improvement and genetic selection should be developed to avoid the birth of calves with extreme weights, particularly those with low birth weight. Considering the higher risk of death among male calves with low vigor and among calves born to very young or very old cows, special attention should be paid to individuals presenting a combination of these traits in order to minimize losses due to death, using management actions. The stillbirth trait should be included as a selection criterion (alone or as part of a selection index) in Nellore breeding programs aiming to reduce preweaning mortality.

\section{References}

ALENCAR, M.M. Parâmetros genéticos da viabilidade de bezerros em um rebanho Canchim. Revista da Sociedade Brasileira de Zootecnia, v.11, p.681-694, 1982.

ALBUQUERQUE, L.G.; MERCADANTE, M.E.Z.; ELER, J.P. Recent studies on the genetic basis for selection of bos indicus for beef production. In: WORLD CONGRESS ON GENETICS APPLIED TO LIVESTOCK PRODUCTION, 8., 2006, Belo Horizonte. Anais... Belo Horizonte: WCGALP, [2006]. (CD-ROM).

AZZAM, S.M.; KINDER, J.E.; NIELSEN, M.K. et al. Environmental effects on neonatal mortality of beef calves. Journal of Animal Science, v.71, p.282-290, 1993.

BLEUL, U. Risk factors and rates of perinatal and postnatal mortality in cattle in Switzerland. Livestock Science, v.135, p.257-264, 2011.
CUNDIFF, L.V.; MACNEIL, M.D.; GREGORY, K.E. et al. Betweenand within-breed genetic analysis of calving traits and survival to weaning in beef cattle. Journal of Animal Science, v.63, p.27-33, 1986.

CUNDIFF, L.V.; GREGORY, K.E.; KOCH, R.M. Germplasm evaluation in beef cattle-cycle IV: birth and weaning traits. Journal of Animal Science, v.76, p.2528-2535, 1998.

ERIKSSON, S.; NÄSHOLM, A.; JOHANSSON, K. et al. Genetic parameters for calving difficulty, stillbirth, and birth weight for Hereford and Charolais at first and later parities. Journal of Animal Science, v.82, p.375-383, 2004.

FUERST-WALTL, B.; FUERST, C. Mortality in Austrian dual purpose Fleckvieh calves and heifers. Livestock Science, v.132, p.80-86, 2010.

GILMOUR, A.R.; GOGEL, B.J.; CULLIS, B.R. et al. ASReml user guide release 3.0. VSN International Ltd, Hemel Hempstead, HP1 1ES, UK, 2008. Available at: <www.vsni.co.uk> Accessed on: May 7, 2009.

GOYACHE, F.; GUTIÉRREZ, J.P.; ALVAREZ, I. et al. Genetic analysis of calf survival at different preweaning ages in beef cattle. Livestock Production Science, v.83, p.13-20, 2003.

GUERRA, J.L.L.; FRANKE, D.E.; BLOUIN, D.C. Genetic parameters for calving rate and calf survival from linear, threshold, and logistic models in a multibreed beef cattle population. Journal of Animal Science, v.84, p.3197-3203, 2006.

HANSEN, M.; MADSEN, P.; JENSEN, J. et al. Genetic parameters of postnatal mortality in Danish Holstein calves. Journal of Dairy Science, v.86, p.1807-1817, 2003.

JOHANSON, J.M.; BERGER, P.J. Birth weight as a predictor of calving ease and perinatal mortality in Holstein cattle. Journal of Dairy Science, v.86, p.3745-3755, 2003.

KATOCH, S.; MANUJA, N.K.; THAKUR, Y.P. et al. Factors affecting calf mortality in organized dairy herd. Indian Journal of Dairy Science, v.46, p.592-594, 1994.

KOCH, R.M.; CUNDIFF, L.V.; GREGORY, K.E. Heterosis and breed effects on reproduction. In: FIELDS, M.J.; SAND, R.S. (Eds.) Factors affecting calf crop. Boca Raton: CRC Press, 1994. p.223-241.

KOOTS, K.R.; GIBSON, J.P.; SMITH, C. et al. Analyses of published genetic parameter estimates for beef production cattle traits. 1. Heritability. Animal Breeding Abstract, v.62, p.309-338, 1994.

MACHADO NETO, R.; PACKER, I.U.; BONILHA NETO, L.M. et al. Concentração de igg sérica em bezerros das raças Nelore, Guzerá, Gir e Caracu. 1. Estatísticas descritivas e causas de variação. Revista Brasileira de Zootecnia, v.26, p.914-919, 1997.

MARTINEZ, M.L.; FREEMAN, A.E.; BERGER, P.J. Genetic relationship between calf livability and calving difficulty of Holsteins. Journal of Dairy Science, v.66, p.1494-1502, 1983.

MAXA, J.; SHARIFI, A.R.; PEDERSEN, J. et al. Genetic parameters and factors influencing survival to 24 hours after birth in Danish meat sheep breeds. Journal of Animal Science, v.87, p.1888-1895, 2009.

MEE, J.F.; BERRY, D.P.; CROMIE, A.R. Prevalence of, and risk factors associated with, perinatal calf mortality in pasture-based Holstein-Friesian cows. Animal, v.2, p.613-620, 2008.

MEIJERING, A. Dystocia and stillbirth in cattle - a review of causes, relations and implications. Livestock Production Science, v.11, p.143-177, 1984.

MERCADANTE, M.E.Z.; RAZOOK, A.G. Programa de melhoramento genético do Instituto de Zootecnia. In: PIRES, A.V. (Ed.) Bovinocultura de corte. Piracicaba: FEALQ, 2010. p.847-860.

MERCADANTE, M.E.Z.; RAZOOK, A.G.; TROVO, J.B.F. et al. Parâmetros genéticos do peso no início da estação de monta, considerado indicativo do peso adulto de matrizes Nelore. Revista Brasileira de Zootecnia, v.33, p.1135-1144, 2004.

MERCADANTE, M.E.Z.; PACKER, I.U.; RAZOOK, A.G. et al. Direct and correlated responses to selection for yearling weight on reproductive performance of Nelore cows. Journal of Animal Science, v.81, p.376-384, 2003. 
MEYER, C.L.; BERGER, P.J.; THOMPSON, J.R. et al. Genetic evaluation of holstein sires and maternal grandsires in the United States for perinatal survival. Journal of Dairy Science, v.84, p.1246-1254, 2001.

MISZTAL, I.; GIANOLA, D.; FOULEY, J.L. Computing aspects of nonlinear method of sire evaluation for categorical data. Journal of Dairy Science, v.53, p.643-650, 1989.

ØSTERÅS, O.; GJESTVANG, M.S.; VATN, S. et al. Perinatal death in production animals in the Nordic countries - incidence and costs. Acta Veterinaria Scandinavica, v.49 (Suppl 1), p.14, 2007.
RAWAL, S.C.; TOMAR, S.S. Inherited variations in mortality and culling rates in Sahiwal female calves up to maturity. Indian Journal of Animal Science, v.64, p.1286-1287, 1994.

RILEY, D.G.; CHASE JR., C.C.; OLSON, T.A. et al. Genetic and nongenetic influences on vigor at birth and preweaning mortality of purebred and high percentage Brahman calves. Journal of Animal Science, v.82, p.1581-1588, 2004.

SOUTHEY, B.; RODRIGUEZ-ZAS, S.; LEYMASTER, K. Discrete time survival analysis of lamb mortality in a terminal sire composite population. Journal of Animal Science, v.81, p.1399-1405, 2003. 